\title{
Effect of Planting-Hole and Fertilizer on Salak (Salacca Zalacca) At Beginning Vegetative Phase
}

\author{
1Didik Hariyono, ${ }^{2}$ Akbar Saitama, ${ }^{3}$ Akbar Hidayatullah Zaini \\ 1,2,3 Department of Agronomy, Faculty of Agriculture, Brawijaya University Jl. Veteran, Malang 65145, Jawa Timur, Indonesia
}

Correspondence Author: Didik Hariyono, Department of Agronomy, Faculty of Agriculture, Brawijaya University, Jl. Veteran, Malang 65145, Jawa Timur, Indonesia.

E-mail: d.hariyono@ub.ac.id

Received date: 23 January 2018, Accepted date: 27 March 2018, Online date: 10 April 2018

Copyright: (C) 2018 Didik Hariyono et al. This is an open-access article distributed under the terms of the Creative Commons Attribution License, which permits unrestricted use, distribution, and reproduction in any medium, provided the original author and source are credited.

\begin{abstract}
Salak (Salacca zalacca) is one of the most important fruit species and become national champions of fruit to native Indonesia. The success of enrichment planting depends on specific planting techniques and treatments applied. Specific planting techniques such as planting-holes was aimed to provide an optimal environment the plant growth of salak. Application of manure were to nourish the rooting space so it can be absorbed by plants. This study was determined to investigate the interaction between the size of planting-hole and manure to the salak growth at the beginning of the vegetative phase. This study was conducted from May until August 2016. This study was using factorial experiment in a randomized block design and repeated 3 times. The first factor was the size of the planting-hole consisting of three levels i.e, L1 (30x30x30) $\mathrm{cm}^{3}, \mathrm{~L} 2$ $(50 \times 50 \times 50) \mathrm{cm}^{3}$ and L3 $(70 \times 70 \times 70) \mathrm{cm}^{3}$. The second factor were manure which consists of three levels i.e, P1 (5 kg/plantinghole), P2 (7.5 kg/planting-hole), and P3 (10 kg/planting-hole). The results showed that interaction on the parameters of plant length, average leaf length, number of dead leaves, number of tillers, and leaf maturation age. The treatment of planting-hole size $(30 \times 30 \times 30) \mathrm{cm}^{3}$ with manure addition $7.5 \mathrm{~kg}$ showed higher plant growth on parameter of plant length, leaf length, with longer leaf maturation lifespan. Planting-hole was significantly reduce on the number of leaves by using treatment $(30 \times 30 \times 30) \mathrm{cm}^{3}$. Application of manure were higher to the number of dead leaves at 4 WAP with manure addition $5 \mathrm{~kg}$ than other treatments.
\end{abstract}

Key words: Planting-hole, Manure, Salak, Salacca zalacca.

\section{INTRODUCTION}

Salak (Salacca zalacca) is an annual tropical fruit native to Indonesia, that can be harvested throughout the year. Salak fruit trees with palm shrubs or barely stalked with very many spines [1]. Salak tree stems have long spines and many with compound pinnate leaves. The fruits of the triangular-shaped triangle-shaped plants are round or oval with pointed at the base and rounded at the ends covered by scaly yellow-brown to red brown skin [2]. Sarkotesta or middle fruit wall has a thick creamy fleshy texture of creamy white yellow and some have reddish-colored fruits, some have sweet, sour, and even spicy flavors with blackish-brown black beans in the center. Data of Central Bureau of Statistic Indonesia stated that the exports of fruits increased by US \$1.74 million in 2014 and it is expected continue to rise. Therefore, increasing production of salak in the near future is necessary by extending and accelerating the plant growth as one solution [3].

Plant growth is inseparable from the environment, particularly the growing media factor. Different planting-holes treatment were aimed to provide an optimal environment for plant in the early growth, returning to plant normal condition after transplanting, and enabling the root-penetration to the soil, so the roots can grow optimumly [4]. [5] stated that planting-holes could increase early root grow more quickly, supporting the plant to absorb nutrients efficiently, and not limit the spreading of early roots on planting medium. Manure addition as backfill on the planting-hole intended to nourish the rooting space, so it can be easier to be absorbed by roots. [6] stated that organic fertilizers can improve soil structure, increase water absorption, increase the quantity of soil microorganism, and source of nutrients for plants. [7] stated that the function of goat manure were able to develop some nutrients such as phosphorus, nitrogen, sulfur, cations and release $\mathrm{P}$ element from oxidation of Fe on soil and forming a complex compound with macro and micro elements, so the plant can reduce the leaching of the element contains.

\section{MATERIALS AND METHODS}

This study was conducted from May until August 2016 at UB Agro Techno Park located in Kebun Jatikerto, Kromengan District, Malang with altitude of 303 meter above sea level. The tools that were used in this research include hoes and shovels, scales, bucket, tape measure, a package of soil analysis tools, cameras, and stationery. The materials used include salak of the transplant seedlings 6 month old goat manure that has been refined, NPK, board labels, and a package of chemicals for soil analysis. The method used was factorial experiment arranged in a randomized block design (RBD), the first factor was the size of the planting-hole consisting of three levels i.e. L1 $(30 \times 30 \times 30) \mathrm{cm}^{3}$, L2 (50x50x50) $\mathrm{cm}^{3}$, and L3 $(70 \times 70 \times 70) \mathrm{cm}^{3}$. The second factor was the dose of goat manure which consists of three levels i.e. P1 (5 kg/planting-hole), P2 (7.5 kg/planting-hole), and P3 (10 kg/planting-hole). Each treatment contained 10 plants and repeated 3 times, so that the overall plant total were 270 plants.

The oobservations were including plant length $(\mathrm{cm})$, leaf lenght $(\mathrm{cm})$, number of leaves, number of dead leaves, number of suckers, leaf maturation age (days) and tillers emerged age (week), which was observed in 4, 6, 8, 10, 12, 14, and 16 WAP. Data of the Salak were recorded and subjected to one-way analysis of variance (ANOVA) at the significant level of 5\%. If there was a significantly different, it will be continued by Fisher's Least Significant Differences (LSD) test at the 0.05 probability [8]. 
Citation: Didik Hariyono, Akbar Saitama, Akbar Hidayatullah Zaini, 2018. Effect of Planting-Hole and Fertilizer on Salak (Salacca Zalacca) At Beginning Vegetative Phase. Advances in Environmental Biology., 12(3): 13-16.

\section{RESULTS AND DISCUSSION}

The interaction between the size of Planting-hole and Manure on Plant Growth of Salak:

Treatment of planting-hole and manure showed a significant interaction on the plant growth of salak to the number of tillers, leaf maturation ages, number of dead leaves at 16 WAP, plant length at 6 WAP to 16 WAP, and leave length at $6 \mathrm{WAP}$ to 16 WAP.

Plant length observation at 6 WAP showed a significant interaction in the treatment of planting-hole size and manure with values from $85.40 \mathrm{~cm}$ to 135.73 $\mathrm{cm}$. This rates was increasing until $16 \mathrm{WAP}$ from $116.60 \mathrm{~cm}$ to $161.33 \mathrm{~cm}$ (Table 1). Similarly, the variable of leaves length at $6 \mathrm{WAP}$ ranging from $64.49 \mathrm{~cm}$ to $102.48 \mathrm{~cm}$. This value also increaseing until 16 WAP between $86.09 \mathrm{~cm}$ to $114.27 \mathrm{~cm}$ (Table 2).

There were a significant interaction of planting-hole size with the amount of manure to the number of dead leaves at 16 WAP (Table 3 ). It indicated that the older plant life will need a more suitable environment and adequate nutrition. According to [9], the addition of organic matter can increase the capacity of water absorption on sandy soil, improve soil aeration with dominant clay texture, and reduce potential of soil compaction. Planting-hole backfill without added organic matter could support plant growth, the addition of organic matter could reduce the potential plant growth because when immersed in the planting-hole will having a decomposition process and there will be a nitrogen used competition in thr roots, so that could make the plant was not grow optimally.

In a variable number of tillers and leaf maturation age showed that the average value that appears contained in the planting-hole treatment $(50 \mathrm{x} 50 \mathrm{x} 50) \mathrm{cm}^{3}$ and manure $7.5 \mathrm{~kg}$ (Table 3). This happens because the salak of plants have a good adaptation, it means that the application of the planting-hole size and various doses of manure could support plant growth of salak so there was no stagnation.

Table 1: Plant lenght of Salak on the treatment planting-hole and manure

\begin{tabular}{|c|c|c|c|c|c|c|c|}
\hline \multirow{2}{*}{$\begin{array}{l}\text { Treatment } \\
\text { Planting-hole }\end{array}$} & \multirow[b]{2}{*}{ Manure } & \multicolumn{6}{|c|}{ Plant Lenght $(\mathrm{cm})$ at observation periods (WAP) } \\
\hline & & 6 & 8 & 10 & 12 & 14 & 16 \\
\hline \multirow[t]{3}{*}{$(30 \times 30 \times 30) \mathrm{cm}^{3}$} & $5 \mathrm{~kg}$ & $104.67 \mathrm{ab}$ & $104.33 \mathrm{ab}$ & $137.67 \mathrm{abc}$ & $138.80 \mathrm{abc}$ & $134.33 \mathrm{ab}$ & $139.00 \mathrm{abc}$ \\
\hline & $7.5 \mathrm{~kg}$ & $116.00 \mathrm{bc}$ & $126.33 \mathrm{bc}$ & $157.73 \mathrm{c}$ & $160.93 \mathrm{c}$ & $161.27 \mathrm{c}$ & $161.33 \mathrm{c}$ \\
\hline & $10 \mathrm{~kg}$ & $98.47 \mathrm{ab}$ & $109.80 \mathrm{ab}$ & $128.13 \mathrm{abc}$ & $130.40 \mathrm{ab}$ & $130.20 \mathrm{a}$ & $128.53 \mathrm{ab}$ \\
\hline \multirow[t]{3}{*}{$(50 \times 50 \times 50) \mathrm{cm}^{3}$} & $5 \mathrm{~kg}$ & $115.93 \mathrm{bc}$ & $122.73 \mathrm{abc}$ & $133.07 \mathrm{abc}$ & $140.87 \mathrm{bc}$ & $140.67 \mathrm{abc}$ & $141.27 \mathrm{bc}$ \\
\hline & $7.5 \mathrm{~kg}$ & $85.40 \mathrm{a}$ & $92.87 \mathrm{a}$ & $117.07 \mathrm{a}$ & $116.87 \mathrm{a}$ & $119.80 \mathrm{a}$ & $116.60 \mathrm{a}$ \\
\hline & $10 \mathrm{~kg}$ & $124.93 \mathrm{bc}$ & $130.87 \mathrm{bc}$ & $144.20 \mathrm{bc}$ & $145.53 \mathrm{bc}$ & $136.47 \mathrm{ab}$ & $129.33 \mathrm{ab}$ \\
\hline \multirow[t]{3}{*}{$(70 \times 70 \times 70) \mathrm{cm}^{3}$} & $5 \mathrm{~kg}$ & $135.73 \mathrm{c}$ & $150.00 \mathrm{c}$ & $148.13 \mathrm{c}$ & $155.27 \mathrm{c}$ & $153.00 \mathrm{bc}$ & $146.40 \mathrm{bc}$ \\
\hline & $7.5 \mathrm{~kg}$ & $96.80 \mathrm{ab}$ & $110.27 \mathrm{ab}$ & $130.00 \mathrm{abc}$ & $126.00 \mathrm{ab}$ & $126.60 \mathrm{a}$ & $128.33 \mathrm{ab}$ \\
\hline & $10 \mathrm{~kg}$ & $101.20 \mathrm{ab}$ & $109.27 \mathrm{ab}$ & $121.67 \mathrm{ab}$ & $130.87 \mathrm{ab}$ & $130.60 \mathrm{ab}$ & $130.33 \mathrm{ab}$ \\
\hline LSD 5\% & & 29.97 & 31.77 & 23.47 & 23.45 & 22.46 & 22.89 \\
\hline
\end{tabular}

Description: Means followed by the same letter at the same age on the column showed no significant difference based on LSD test at level 5\%; WAP $=$ Weeks After Planting.

Table 2: Leaves length of Salak on the treatment planting-hole and manure

\begin{tabular}{|c|c|c|c|c|c|c|c|}
\hline \multirow{2}{*}{$\begin{array}{l}\text { Treatment } \\
\text { Planting-hole }\end{array}$} & & \multicolumn{6}{|c|}{ Leaves length $(\mathrm{cm})$ on observation periods (WAP) } \\
\hline & Manure & 6 & 8 & 10 & 12 & 14 & 16 \\
\hline \multirow[t]{3}{*}{$(30 \times 30 \times 30) \mathrm{cm}^{3}$} & $5 \mathrm{~kg}$ & $77.50 \mathrm{ab}$ & $81.33 \mathrm{ab}$ & $96.95 \mathrm{abcd}$ & $99.25 \mathrm{abcd}$ & $96.74 \mathrm{abc}$ & $100.05 \mathrm{abc}$ \\
\hline & $7,5 \mathrm{~kg}$ & $84.46 \mathrm{abc}$ & $91.36 \mathrm{bc}$ & $109.44 \mathrm{~d}$ & $110.97 \mathrm{~d}$ & $112.79 \mathrm{c}$ & $114.27 \mathrm{c}$ \\
\hline & $10 \mathrm{~kg}$ & $74.28 \mathrm{ab}$ & $78.18 \mathrm{ab}$ & $89.20 \mathrm{ab}$ & $92.83 \mathrm{ab}$ & $94.62 \mathrm{ab}$ & $93.27 \mathrm{ab}$ \\
\hline \multirow[t]{3}{*}{$(50 \times 50 \times 50) \mathrm{cm}^{3}$} & $5 \mathrm{~kg}$ & $84.05 \mathrm{abc}$ & $89.56 \mathrm{bc}$ & $93.49 \mathrm{abcd}$ & $95.69 \mathrm{abc}$ & $93.59 \mathrm{ab}$ & $95.55 \mathrm{ab}$ \\
\hline & $7,5 \mathrm{~kg}$ & $64.49 \mathrm{a}$ & $67.75 \mathrm{a}$ & 84.17 a & $85.78 \mathrm{a}$ & $88.80 \mathrm{a}$ & $86.09 \mathrm{a}$ \\
\hline & $10 \mathrm{~kg}$ & $93.68 \mathrm{bc}$ & $96.78 \mathrm{bc}$ & $103.19 \mathrm{bcd}$ & $105.07 \mathrm{bc}$ & $103.57 \mathrm{abc}$ & $94.41 \mathrm{ab}$ \\
\hline \multirow[t]{3}{*}{$(70 \times 70 \times 70) \mathrm{cm}^{3}$} & $5 \mathrm{~kg}$ & $102.48 \mathrm{c}$ & $110.35 \mathrm{c}$ & $106.64 \mathrm{~cd}$ & $110.85 \mathrm{~cd}$ & $109.61 \mathrm{bc}$ & $106.37 \mathrm{bc}$ \\
\hline & $7,5 \mathrm{~kg}$ & $73.93 \mathrm{ab}$ & $81.92 \mathrm{ab}$ & $93.34 \mathrm{abc}$ & $91.43 \mathrm{ab}$ & $93.43 \mathrm{ab}$ & $94.52 a b$ \\
\hline & $10 \mathrm{~kg}$ & $76.75 \mathrm{ab}$ & $81.09 \mathrm{ab}$ & $89.32 \mathrm{ab}$ & $91.91 \mathrm{ab}$ & $93.22 \mathrm{ab}$ & $92.74 \mathrm{ab}$ \\
\hline LSD 5\% & & 21.28 & 21.15 & 15.76 & 15.25 & 16.40 & 14.82 \\
\hline
\end{tabular}

Description: Means followed by the same letter at the same age on the column showed no significant difference based on LSD test at level $5 \%$; WAP = Weeks After Planting.

Table 3: Number of dead leaves, number of tillers, and leaf maturation age of Salak on the treatment planting-hole and manure

\begin{tabular}{|c|c|c|c|c|}
\hline \multicolumn{2}{|l|}{ Treatment } & \multirow{2}{*}{$\begin{array}{l}\text { Number of Dead Leaves (per } \\
\text { plant) } \\
16 \text { WAP }\end{array}$} & \multirow{2}{*}{$\begin{array}{l}\text { Number of Tillers } \\
\text { (per plant) }\end{array}$} & \multirow{2}{*}{$\begin{array}{l}\text { Leaf Maturation Age } \\
\text { (days) }\end{array}$} \\
\hline Planting-hole & Manure & & & \\
\hline \multirow[t]{3}{*}{$(30 \times 30 \times 30) \mathrm{cm}^{3}$} & $5 \mathrm{~kg}$ & $0.60 \mathrm{c}$ & $0.00 \mathrm{a}$ & $54.20 \mathrm{a}$ \\
\hline & $7.5 \mathrm{~kg}$ & $0.27 \mathrm{ab}$ & $0.07 \mathrm{a}$ & $59.87 \mathrm{bc}$ \\
\hline & $10 \mathrm{~kg}$ & $0.40 \mathrm{bc}$ & $0.00 \mathrm{a}$ & $57.07 \mathrm{ab}$ \\
\hline \multirow[t]{3}{*}{$(50 \times 50 \times 50) \mathrm{cm}^{3}$} & $5 \mathrm{~kg}$ & $0.07 \mathrm{a}$ & $0.00 \mathrm{a}$ & $60.33 \mathrm{bc}$ \\
\hline & $7.5 \mathrm{~kg}$ & $0.33 \mathrm{abc}$ & $0.60 \mathrm{~b}$ & $62.60 \mathrm{c}$ \\
\hline & $10 \mathrm{~kg}$ & $0.47 \mathrm{bc}$ & $0.13 \mathrm{a}$ & $55.27 \mathrm{a}$ \\
\hline \multirow[t]{3}{*}{$(70 \times 70 \times 70) \mathrm{cm}^{3}$} & $5 \mathrm{~kg}$ & $0.33 \mathrm{abc}$ & $0.20 \mathrm{a}$ & $55.33 \mathrm{a}$ \\
\hline & $7.5 \mathrm{~kg}$ & $0.40 \mathrm{bc}$ & $0.07 \mathrm{a}$ & $55.13 \mathrm{a}$ \\
\hline & $10 \mathrm{~kg}$ & $0.27 \mathrm{ab}$ & $0.20 \mathrm{a}$ & $60.87 \mathrm{c}$ \\
\hline LSD 5\% & & 0.32 & 0.31 & 3.66 \\
\hline
\end{tabular}

Description: Means followed by the same letter at the same age on the column showed no significant difference based on LSD test at level $5 \%$; WAP $=$ Weeks After Planting.

Effect of Planting-hole to the Plant Growth of Salak:

Treatment of planting-hole size had significant effect on the number of leaf at 10 WAP and 16 WAP (Table 4), because the size of the planting-hole could affect the root growth, so it can absorb more nutrients and having optimum photosynthate to stimulate the vegetative growth on plant organ such as leaves. [10] stated that larger planting-hole size on solid ground (predominantly clay) can accelerate the growth of roots, providing space for new roots to grow in the loose soil, strengthening the plants after transplanting, and improve plant adaptation to the new environment. [11] stated that root growth were improved with an increase on the size of the planting-hole and improvement of root growth direction to finding nutrients in the soil. However, [12] stated that plant in the smaller planting-hole can be grown in the same level with plants in the larger planting-hole size with the addition of nutrients. [13] suggested that root competition had no significant effect on early seedling growth. 
Citation: Didik Hariyono, Akbar Saitama, Akbar Hidayatullah Zaini, 2018. Effect of Planting-Hole and Fertilizer on Salak (Salacca Zalacca) At Beginning Vegetative Phase. Advances in Environmental Biology., 12(3): 13-16.

Table 4: Number of leaves Salak on the treatment planting-hole and manure

\begin{tabular}{lll}
\hline Treatment & \multicolumn{2}{l}{ Number of leaves (per plant) at observation periods (WAP) } \\
\cline { 2 - 3 } & 10 & 16 \\
\hline Planting-hole & $8.87 \mathrm{a}$ & $9.80 \mathrm{a}$ \\
$(30 \times 30 \times 30) \mathrm{cm}^{3}$ & $10.93 \mathrm{~b}$ & $11.87 \mathrm{~b}$ \\
$(50 \times 50 \times 50) \mathrm{cm}^{3}$ & $11: 13 \mathrm{~b}$ & $12: 20 \mathrm{~b}$ \\
$(70 \times 70 \times 70) \mathrm{cm}^{3}$ & $12: 57$ & $12: 56$ \\
\hline LSD 5\% & 9.67 & 10.60 \\
\hline Doses manure & $11: 53$ & $12: 33$ \\
$5 \mathrm{~kg}$ & 9.73 & 10.93 \\
$7.5 \mathrm{~kg}$ & $\mathrm{~ns}$ & $\mathrm{~ns}$
\end{tabular}

Description: Means followed by the same letter at the same age on the column showed no significant difference based on LSD test at level 5\%; ns $=$ not significant; WAP = Weeks After Planting.

\section{Effect of Manure to the Plant Growth of Salak:}

Manure application was significantly affect the number of dead leaves at observation of 4 WAP (Table 5). Reduction in the number of leaves could decrease the photosynthesis rate, which is nutrient also plays a role in the plant metabolic activity [14]. This condition occurs because of the characteristic of a slowrelease fertilizer, so that in the early plant growth nutrients was not yet available to plants. In the variable number of dead leaves showed that the average value of number of dead leaves, that appear on the treatment of manure $5 \mathrm{~kg}$ in 4 WAP was higher than other treatments. In the research [15], found that the addition of organic matter to improve the growth and yield of onion. [16] described goat manure application continously could provide a positive impact on soil fertility, so it will facilitate the developments of plant roots. The thrive plant roots will be easier to absorb water and nutrients available in the soil so plants can grow and develop optimally and produce high yields. [17] found that the addition of cow manure had significant effect on plant growth. [18] found that the interaction of urea fertilizer application and manure goat significantly increase the dry weight of the plant roots. [19] stated that provision of goat manure fertilizer can increase the availability of nutrients in the soil, so the plants will have an optimum growth and increasing rate of photosynthesis.

Table 5: Number of dead leaves of Salak on the treatment planting-hole and manure

\begin{tabular}{ll}
\hline & \multicolumn{1}{l}{ Table 5: Number of dead leaves of Salak on the treatment planting-hole and manure } \\
\hline & $\begin{array}{l}\text { Number of dead leaves at observation } \\
\text { periods (WAP) }\end{array}$ \\
\cline { 2 - 2 } & 4 WAP \\
\hline Planting-hole & 0.73 \\
$(30 \times 30 \times 30) \mathrm{cm}^{3}$ & 0.73 \\
$(50 \times 50 \times 50) \mathrm{cm}^{3}$ & 0.47 \\
\hline LSD 5\% & $\mathrm{ns}$ \\
\hline Manure dose & $1.13 \mathrm{~b}$ \\
$5 \mathrm{Kg}$ & $0.33 \mathrm{a}$ \\
$7.5 \mathrm{~kg}$ & $0.47 \mathrm{a}$ \\
\hline LSD Kg $5 \%$ & 0.27 \\
\hline
\end{tabular}

Descriptions: Means followed by the same letter at the same age on the column showed no significant difference based on LSD test at level 5\%; ns $=$ not significant; WAP = Weeks After Planting.

\section{Conclusion:}

Based on the research that has been done can be concluded that in this study the interaction between the planting-hole size and manure application on plant growth (Salacca zalacca) in the vegetative phase beginning at length parameter at 6 WAP to 16 WAP, the average of leaf lenght age 6 to 16 WAP, the number of dead leaves observation 16 WAP number of tillers and leaf maturation age.

\section{Conflict Of Interest:}

The authors declared that present study was performed in absence of any conflict of interest.

\section{ACKNOWLEDGMENT}

The researcher expressed gratitude to Adi Suwandono who has helped the research until the completion of research conducted by the author.

\section{REFERENCES}

[1] Gustini, D., S. Fatonah and Sujarwat, 2012. Effect of Rootone F and Bayfolan Fertilizer on Initiation of Root and Growth of Salak Pondoh (Salacca edulis Reinw.) Seedlings. Biospecies, 5(1): 8-13.

[2] Rizal, M., D.M. Purwantiningdyah and R. Widowati, 2015. Study of Salak Fruit Post Harvest and its Economic Analysis in Balikpapan City, East Kalimantan. Biodiversitas, 1(5): 1238-1244.

[3] Ariviani, S and N.H.R. Parnanto, 2013.Antioxidant Capacity of Snake Fruit (Salacca edulis Reinw) Cultivar Pondoh, Nglumut, Bali and Its Correlation to Total Phenolics and Ascorbic Acid Content. Agritech, 3(33): 324-333.

[4] Hariyono, D., 2018. The Effect Planting Hole Size and Manure on Vegetative Growth of Golden Teak (Tectona grandis L.). J. Degraded Mining Land Management, 5(3): 1293-1297.

[5] Watson, G.W., 1997. Tree Transplanting and Establishment. Arnoldia.

[6] Uwah, D.F and V.E. Eyo, 2014. Effects of number and rate of goat manure application on soil properties, growth and yield of sweet maize (Zea mays L. saccharata Strut). Sustainable Agriculture Research, 3(4): 76-83.

[7] Suwardjono, 2003. The Influence of Some Kinds of Manure on Peanut Growth and Production. J. Matematika Sains Teknologi., 2: 11-18.

[8] Gomez, K.A., A.A. Gomez, 1984. Statistical Procedures for Agricultural Research. 2nd ed, John Wiley and Sons, New York.

[9] Schuch, U.K., J. Kelly and F. Stryker, 2003. Effect of Planting-hole Size and Amendments on Growth and Establishment of Acacia farnesiana. Tuscon, Plant Sciences Department, University of Arizona AZ 85721.

[10] Gilman, E.F. and L. Sadowski, 2010. Planting and Establishing Trees, Florida University of Florida, IFAS Extension.

[11] Watson, G.W., G. Kupkowski and V.G. Heide-Spravka, 1993. Influence of Backfill Soil Amendments on Establishment of Container-grown Shrubs. Horticulture Technology, 3: 188-189.

[12] Vincent, A and S.J. Davis, 2003. Effects of Nutrient Addition, Mulching and Planting-Hole Size on Early Performance of Dryobalanops aromatica and Shorea parvifolia Planted in Secondary Forest in Sarawak, Malaysia. Forest Ecology and Management. Elsevier Journal, 180: $261-271$. 
[13] Pinard, M.A., D.W. Davidson and A. Ganing, 1998. Effects of Trenching on Growth and Survival of Planted Shorea parvifolia Seedlings under Pioneer Stands in a Logged-Over Forest. J. of Tropical Forest Science., 10: 505-514.

[14] Rastiyanto, E., A. Sutirman and A. Pullaila, 2013. The Effect of Organic Fertilizer of Goat Manure on Growth and Yield of Kailan. IKATAN, 3: 36-40.

[15] Latarang, B and A. Syakur, 2006. Growth and Yield of Shallot (Allium ascalonicum) at Various Dosage of Manure. J. Agroland, 13(3): 265-269.

[16] Dewi, W.W., 2016. Response Dosage Goat Manure to Growth and Yield Cucumber (Cucumis sativus L.) with Hybrid Varieties. J. Viabel Pertanian, 10: 1129.

[17] Surata, I.K, 2009. Effects of Planting-Hole Size and Cowdung Compost for Planting Critical Lands of the Savanna Area in Sumba Island. J. Penelitian Hutan dan Konservasi Alam, 6(2): 147-157.

[18] Putra, A.D., M.M.B. Damanik and H. Hanum, 2015. Urea Fertilizer and Goat Manure Application for Increasing N-Total on Inceptisol Kuala Bekala and Corn Growth (Zea mays L.). J. Online Agroekoteknologi, 3(1): 128-135.

[19] Rihana, S., Y.B.S. Heddy and M.D. Maghfoer, 2013. Growth and Yield of Common Bean (Phaseolus vulgaris L.) on Various Goat Manure Dosage and Concentration of Plant Growth Regulators Dekamon. J. Produksi Tanaman, 1(4): 369-377. 